\title{
POTENSI SERAT DAN PULP BAMBU UNTUK KOMPOSIT PEREDAM SUARA
}

\author{
Theresia Mutia ${ }^{1}$, Susi Sugesty, Henggar Hardiani, Teddy Kardiansyah, Hendro Risdianto \\ Balai Besar Pulp dan Kertas, Jl. Raya Dayeuhkolot No. 132, Bandung \\ ${ }^{1}$ theresia.mutia@yahoo.com
}

Diterima : 10 Maret 2014, Revisi akhir : 21 Mei 2014, Disetujui terbit : 30 Mei 2014

\section{POTENCY OF FIBER AND PULP FROM BAMBOO FOR SOUND ABSORBER COMPOSITE}

\begin{abstract}
Natural fiber-reinforced composites can reduce the use of synthetic fibers and resins, making them more environmentally friendly. Bamboo fiber is a long fiber from non woody plant with a shorter growing season than wood. A study has been conducted to investigate the potential of bamboos, which are endemic in West Java, namely Tali bamboo (G. apus), Temen bamboo (G. pseudoarundinacea) and Haur bamboo/Green ampel (B. vulgaris v. Green), as sound absorber composite materials. Bamboo contains $21 \%-22 \%$ lignin, $44 \%$ - 53\% alpha cellulose, $21 \%$ - 23\% hemicelluloses, which makes it a potential pulp feedstock. Because of the adhesive nature of lignin, it is necessary to produce a pulp with a Kappa number of about $30(+5 \%$ lignin). In accordance with bamboo characteristics, Tali bamboo requires less amount of cooking chemicals due to its lower contents of extractive substances and lignin, whereas Temen bamboo and especially Haur bamboo require more chemicals. Therefore, tali bamboo was chosen to produce pulp by Kraft cooking process. Subsequently, bamboo fiber was prepared by soda cooking process at the same conditions. Later on, some trial experiments with epoxy resin were performed to make sound absorber composites. The results show that at the reference frequency $(5000 \mathrm{~Hz})$ the pulp and bamboo fiber composites provide the maximum sound absorption coefficients $(\alpha)$ of 0.28 and 0.77 , respectively. Hence, the composite meets the minimum standard of sound absorption coefficient of ISO 11654:1997 $(\alpha=0.25)$. Moreover, the composite of epoxy and bamboo fiber is light (specific gravity <1) with an ability to reduce $97 \%$ of the sound at $2500 \mathrm{~Hz}$.
\end{abstract}

Keywords : fiber and pulp bamboo, nonwood, sound absorber composite, sound absorption coefficien

\begin{abstract}
ABSTRAK
Komposit berpenguat serat alam, dapat mengurangi pemakaian serat sintetis dan resin, sehingga lebih ramah lingkungan. Serat bambu termasuk serat panjang non kayu dengan masa tanam lebih singkat dibanding kayu. Penelitian terhadap bambu endemik Jawa Barat, yaitu bambu Tali (G. apus), Temen ( $G$. pseudoarundinacea) dan Haur/Ampel hijau (B. vulgaris v. green), dilakukan untuk mengetahui potensinya sebagai komposit peredam suara. Dari hasil uji diketahui bahwa bambu tersebut mengandung lignin $21 \%-22 \%$, selulosa alfa 44\% - 53\% dan hemiselulosa $21 \%$ - 23\%, serta merupakan serat panjang yang berpotensi untuk menghasilkan pulp yang baik. Lignin pada pulp untuk bahan komposit masih diperlukan, sehubungan dengan sifatnya sebagai perekat, sehingga dilakukan penelitian untuk menghasilkan pulp bambu dengan bilangan Kappa sekitar 30 (lignin $\pm 5 \%$ ). Atas dasar karakteristiknya, pemasakan bambu Tali akan memerlukan zat kimia yang terendah karena kandungan zat ekstraktif dan lignin yang lebih rendah, sedangkan bambu Temen dan terutama Haur sebaliknya memerlukan zat kimia yang lebih tinggi. Oleh karenanya dipilih bambu Tali untuk dilanjutkan pada pembuatan pulp dengan pemasakan proses Kraft dan untuk mendapatkan seratnya dilakukan pemasakan dengan proses soda pada kondisi sama, yang kemudian dilakukan uji coba pembuatan komposit peredam suara dengan resin epoksi. Dari hasil uji diketahui bahwa pada frekuensi acuan $(5000 \mathrm{~Hz})$ komposit pulp dan serat bambu memberikan koefisien serap bunyi maksimum $(\alpha)$ sebesar 0,28 dan 0,77, berarti dapat memenuhi standar minimal koefisien serap bunyi sesuai ISO 11654:1997 $(\alpha=0,25)$, terutama komposit epoksi/serat bambu, karena mampu meredam suara sampai $97 \%$ pada frekuensi $2500 \mathrm{~Hz}$, dan lebih ringan (berat jenisnya $<1$ ).
\end{abstract}

Kata kunci: serat dan pulp bambu, non kayu, komposit peredam suara, koefisien serap bunyi 


\section{PENDAHULUAN}

Dewasa ini produk berbahan baku kayu mengalami kendala, karena ketersediaan bahan baku yang semakin terbatas. Bahan baku alternatif non kayu banyak pilihannya, antara lain bambu. Serat bambu adalah serat panjang dengan masa tanam yang cukup singkat dibandingkan dengan kayu, yaitu sekitar 3-5 tahun. Bambu banyak digunakan sebagai bahan bangunan rumah, peralatan rumah tangga, dan lain-lain dan juga pulp kertas serta komposit (Tampobolon, 2010).

Komposit adalah bahan yang terbentuk apabila dua atau lebih komponen yang berlainan digabungkan, misalnya resin/plastik dan bahan penguat berupa serat/anyaman atau lainnya (Pramono, 2012; Chen dkk., 2007; Setyanto dkk., 2011; Mazumdar, 2002). Produk komposit menghasilkan antara lain tekstil teknik, yaitu tekstil yang dibuat untuk fungsi tertentu, dengan lebih mengutamakan sifat-sifat teknik maupun unjuk kerjanya daripada menampilkan karakteristik estetika dan dekoratif. Bahan bakunya antara lain logam, mineral (asbes, serat gelas/karbon), serat alam/sintetik. Salah satu kelompok tekstil teknik adalah tekstil bangunan yang termasuk di dalamnya adalah bahan konstruksi dan arsitektural seperti penguat beton, konstruksi atap, peredam suara, dan lain-lain (Eriningsih dkk., 2011).

Suara yang keras dapat berdampak psikologis dan biologis pada manusia, antara lain menurunnya kenyamanan dan konsentrasi, stres pada sistem kerja jantung, peredaran darah atau pada sistem sirkulasi udara/pernapasan, dan mengganggu komunikasi verbal, bahkan dapat menyebabkan berkurangnya kemampuan pendengaran secara temporer, atau rusaknya indera pendengaran secara permanen (Khuriati dkk., 2006; Beranek dkk., 1992; Merve dkk., 2010). Ada sekitar 500 jenis pekerjaan pada industri yang berpotensi merusak pendengaran (> $85 \mathrm{dBA}$ ), antara lain pada kebisingan antara 85 - 100 dBA (industri tekstil dan garmen, industri yang menggunakan mesin bor listrik dan mesin penggilingan); pekerjaan pada kebisingan antara $100-115 \mathrm{dBA}$ yang terdapat pada industri alat berat (mesin ketel uap, industri logam); pekerjaan kebisingan antara 115-130 dBA (industri kapal terbang, mesin turbo, mesin kompres dan mesin turbin diesel); pekerjaan pada kebisingan antara 130-160 (industri mesin turbo, pesawat terbang besar dan mesin jet).
Pada industri tekstil pertenunan yang menggunakan mesin-mesin modern, umumnya tingkat kebisingannya melebihi nilai ambang batas (NAB) 85 dBA. Kebisingan yang melebihi NAB dapat menyebabkan kelelahan bagi tenaga kerja yang terpapar 8 jam/hari (40 jam/minggu). Berdasarkan hasil penelitian diperoleh rata-rata kebisingan di bagian weaving pada industri tekstil tertentu adalah sebesar 128,74 dBA (melebihi NAB) (Airna, 2011). Untuk mengendalikan kebisingan tersebut, maka perlu memanfaatkan bahan peredam suara yang dapat menyerap energi suara dari suatu sumber suara (Khuriati dkk., 2006; Miasa dkk., 2004; Sabri, 2005). Bahan tersebut pada umumnya dapat diletakkan pada lantai, dinding atau langit-langit ruangan.

Fungsi serat secara umum pada komposit adalah untuk memperkuat, sehingga akan diperoleh produk yang lebih kuat dan kokoh. Selain itu juga untuk mengurangi pemakaian resin (Judawisastra dkk., 2006; Mazumdar, 2002; Eriningsih dkk., 2011; Tampobolon, 2010). Serat alam pada umumnya memiliki kemampuan menyerap suara khususnya dalam mengendalikan kebisingan, karena mempunyai sifat porositas dan struktur amorf yang lebih tinggi dibandingkan serat sintetik. Hasil penelitian menunjukkan bahwa serat kelapa dan rami dapat menyerap suara dengan baik pada frekuensi tinggi (Khuriati dkk., 2006; Franck, 2005; Merve dkk., 2010).

Berbagai macam bahan telah digunakan untuk bahan baku komposit dalam upaya mendapatkan bahan yang tepat guna. Pulp atau serat bambu sampai saat ini belum secara optimal digunakan sebagai substitusi serat sintetis, material gelas, plastik, logam atau bahan konvensional lainnya; yang umum digunakan untuk pembuatan berbagai produk oleh industri. Selain itu, komposit dengan penguat serat bambu, seperti juga komposit berbahan dasar serat alam diharapkan memiliki karakteristik yang lebih baik, yaitu mudah didapat, lebih murah, lebih ringan, ramah lingkungan dan dapat mengurangi penggunaan serat sintetis dan resin.

Oleh karenanya telah dilakukan penelitian terhadap tiga jenis bambu endemik Jawa Barat, yaitu bambu Tali (G. apus), bambu Temen (G. pseudoarundinacea) dan bambu Haur/Ampel hijau (B. vulgaris v. green) agar dapat diketahui karakteristik dari pulp dan serat bambu yang nantinya dapat digunakan sebagai bahan baku komposit. Penelitian awal ini difokuskan untuk mendapatkan metode pembuatan pulp dan serat 
dari beberapa jenis bambu untuk kemudian dipilih jenis bambu dengan penggunaan bahan kimia minimal. Selanjutnya, pulp dan serat bambu dari bambu yang terpilih diuji coba sebagai bahan baku komposit untuk produk peredam suara.

\section{BAHAN DAN METODE}

\section{Bahan Baku dan Bahan Kimia}

Bahan baku yang digunakan adalah bambu yang berumur sekitar tiga tahun, yaitu bambu Tali, bambu Temen dan bambu Haur. Bahan kimia yang digunakan yaitu soda kostik dan natrium sulfida.

\section{Peralatan}

Alat penyerpih kayu, peralatan gelas lengkap, Rotary Digester, Mechanical Softening \& Brushing, Hot Press

\section{Cara Kerja}

\section{Pembuatan Pulp}

Bambu dipotong kecil-kecil menjadi chip kemudian dibuat pulp proses Kraft dengan rasio 1:5, alkali aktif $14 \%$ sampai dengan $24 \%$ (interval $2 \%$ ), sulfiditas $25 \%$ dan $32 \%$, suhu $165^{\circ} \mathrm{C}$ selama 120 menit dan direfiner dua kali. Target kandungan lignin yang ingin dicapai adalah sekitar 5\% agar serat tidak regas/mudah putus.

\section{Penguraian Serat Bambu}

Untuk mendapatkan serat bambu sebagaibahan komposit, maka bambu dipotong-potong terlebih dahulu dengan panjang sekitar $25 \mathrm{~cm}$, kemudian dilakukan pemasakan untuk menghilangkan sebagian kadar ligninnya, kemudian disisir dan diratakan melalui alat Mechanical Softening \& Brushing. Pemasakan dilakukan dengan rasio 1:5, soda kostik $12 \%$, suhu $165^{\circ} \mathrm{C}$ selama 120 menit

\section{Pembuatan Komposit}

\section{- Penentuan Komposisi Komposit}

Dalam penelitian ini dilakukan proses pembuatan komposit dengan matriks resin epoksi. Serat alam sebagai penguat komposit yang digunakan dalam penelitian ini adalah pulp dan serat bambu dari bambu yang terpilih.

Pembuatan komposit untuk absorpsi suara diawali dengan percobaan awal untuk menentukan komposisi komposit agar mendapatkan kondisi proses yang optimal. Percobaan dilakukan dengan menggunakan resin epoksi dan dilakukan dengan perbandingan fraksi pulp atau serat terhadap fraksi resin yaitu $1: 1 ; 1: 1,25 ; 1: 1,5 ; 1: 1,75$ dan $1: 2$.

\section{- Pencetakan dan Pengeringan}

Setelah komposisi komposit dibuat, bahan dicampur dan diaduk. Campuran tersebut dimasukan ke dalam cetakan, kemudian dipres dengan tekanan $60 \mathrm{~kg} / \mathrm{cm}^{2}$ selama 2 jam. Selanjutnya dilakukan pengeringan dengan menggunakan oven pada suhu $70^{\circ} \mathrm{C}$ selama satu jam. Adapun untuk keperluan uji absorpsi suara, maka diperlukan contoh uji berdiameter sekitar $30 \mathrm{~mm}$, maka pembuatan komposit dilakukan dengan bantuan alat khusus, sesuai dengan ISO 10534-2:2001.

\section{- Menimbang dan Mengukur Sampel}

Contoh uji (komposit) yang sudah jadi kemudian ditimbang dan diukur tinggi dan diameternya untuk mengetahui volumenya. Penentuan berat dan volume sampel ini digunakan untuk mengetahui massa.

\section{Pengujian}

Pengujian dilakukan untuk menentukan a). diameter dan tebal bambu (menggunakan jangka sorong); b). morfologi serat bambu (menggunakan mikroskop); c). besaran nilai turunan dimensi serat (Syafii dan Siregar, 2006; Fitriasari dan Hermiati, 2008); d). skor dimensi serat (Syafii dan Siregar, 2006; Fitriasari dan Hermiati, 2008); e). Analisis komponen kimia yang terdiri dari:

- Kadar air, sesuai dengan SNI 08-70702005, Cara uji kadar air pulp dan kayu dengan metode pemanasan dalam oven

- Kadar abu dan kadar silikat, sesuai dengan SNI ISO 776:2010, Pulp-Cara uji kadar abu tidak larut asam

- Lignin, sesuai dengan SNI 0492-2008, Cara uji kadar lignin kayu dan pulp (Metode Klason) 
- Pentosan, sesuai dengan SNI 14-13041989, Cara uji kadar pentosan dalam pulp kayu

- Ekstraktif (Ekstrak Alkohol-Benzena), sesuai dengan SNI 14-1032-1989, Cara uji kadar sari (Ekstrak Alkohol-Benzen) dalam kayu dan pulp

- Holoselulosa, sesuai dengan SNI 011303-1989, Cara uji holoselulosa dalam kayu

- Selulosa alfa, sesuai dengan dengan SNI 0444:2009, Cara uji kadar selulosa alfa, beta dan gamma

- Kelarutan air dingin dan air panas dan dingin, sesuai dengan SNI 01-1305-1989, Cara uji kelarutan kayu dan pulp dalam air dingin dan air panas,

dan f). Absorpsi suara sesuai dengan ISO 10534-2:2001, Acoustics - Determination of sound absorption coefficient and impedance in impedance tubes - Part 2: Transfer-Function Method. 1998. International Standardization Organization

\section{HASIL DAN PEMBAHASAN}

\section{Bahan Baku}

Pada penelitian ini digunakan 3 jenis bambu, yaitu bambu Tali, bambu Temen dan bambu Haur (Ampel hijau). Untuk mengetahui karakteristiknya, maka dilakukan serangkaian pengujian, meliputi uji diameter dan tebal batang, morfologi serta komponen kimianya. Adapun hasilnya disajikan pada Gambar 1 dan Gambar 2, serta Tabel 1 dan Tabel 2.

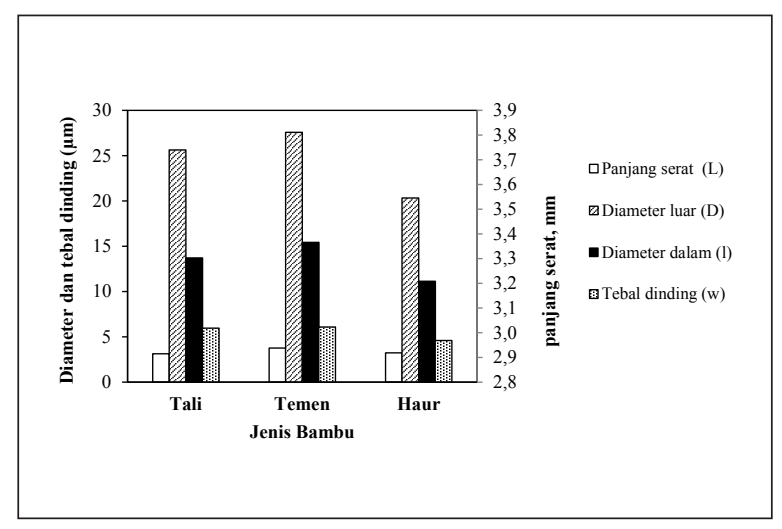

Gambar 1.a. Morfologi Serat Bambu

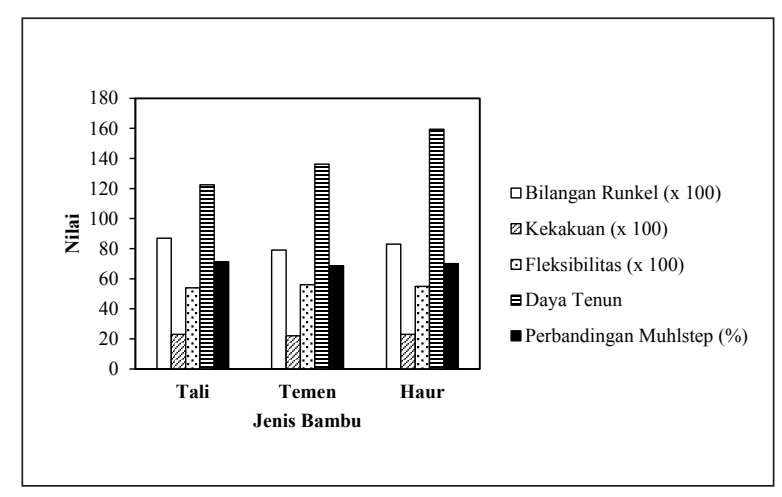

Gambar 1.b. Morfologi Serat Bambu

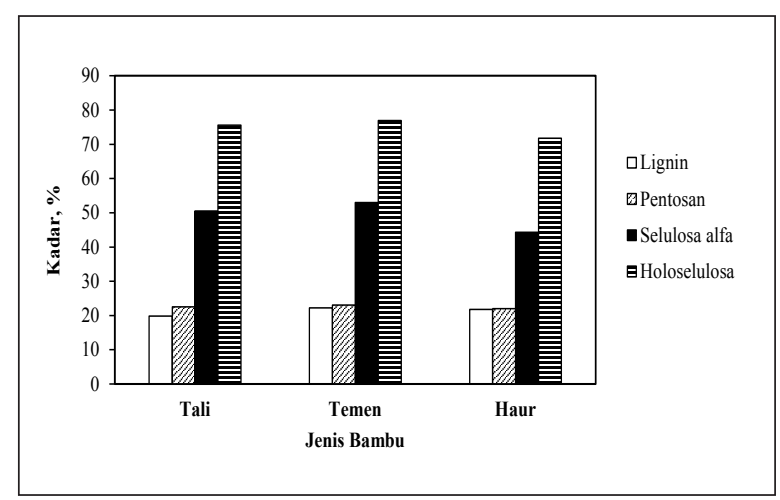

Gambar 2.a. Komponen Kimia Serat Bambu

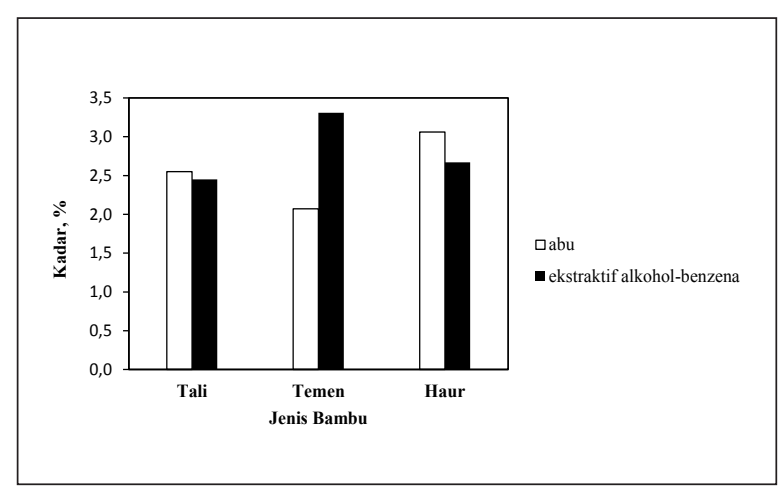

Gambar 2.b. Komponen Kimia Serat Bambu

Tabel 1. Besaran Nilai Turunan Dimensi Serat Bambu

\begin{tabular}{lccc}
\hline \multirow{2}{*}{\multicolumn{1}{c}{ Parameter }} & \multicolumn{3}{c}{ Jenis Bambu } \\
\cline { 2 - 4 } & Haur & Tali & Temen \\
\hline Bilangan Runkel, 2w/1 & 0,83 & 0,87 & 0,79 \\
Kekakuan, w/D & 0,23 & 0,23 & 0,22 \\
Fleksibilitas, 1/D & 0,55 & 0,54 & 0,56 \\
Daya Tenun, L/D & 159,45 & 122,56 & 136,33 \\
Perbandingan Muhlstep (\%) & 70 & 71,36 & 68,70 \\
\hline
\end{tabular}


Tabel 2. Penetapan Skor Dimensi Serat dan Nilai Turunannya pada 3 Jenis Bambu untuk Penentuan Klasifikasi Seratnya

\begin{tabular}{lccc}
\hline \multirow{2}{*}{\multicolumn{1}{c}{ Parameter }} & \multicolumn{3}{c}{ Jenis Bambu } \\
\cline { 2 - 4 } & Haur & Tali & Temen \\
\hline Panjang Serat & 100 & 100 & 100 \\
Bilangan Runkel, 2w/1 & 50 & 50 & 50 \\
Kekakuan, w/D & 25 & 25 & 25 \\
Fleksibilitas, 1/D & 50 & 50 & 50 \\
Daya Tenun, L/D & 100 & 100 & 100 \\
Perbandingan Muhlstep (\%) & 50 & 50 & 50 \\
Skor Total & 375 & 375 & 375 \\
\hline
\end{tabular}

\section{Diameter dan Tebal Bambu}

Dari hasil uji diketahui bahwa diameter ketiga bambu tersebut berkisar antara $5,85 \mathrm{~cm}-$ $6,6 \mathrm{~cm}$, sedangkan tebalnya berkisar antara 0,95 $\mathrm{cm}-1,1 \mathrm{~cm}$.

\section{Dimensi Serat}

Dimensi serat merupakan salah satu sifat penting bahan baku yang dapat digunakan sebagai dasar memilih bahan baku untuk produksi pulp dan kertas. Dari Tabel diketahui bahwa panjang serat bambu secara umum di atas 3 milimeter. Menurut klasifikasi IAWA, serat bambu termasuk kelas serat panjang yaitu minimal $1,6 \mathrm{~mm}$, maksimal 4,4 $\mathrm{mm}$ dan rata-rata 2,7 $\mathrm{mm}$ (Fitriasari dan Hermiati, 2008).

Menurut Tamolang dan Wangaard (1961) dalam Pasaribu dan Tampubolon (2007), bahwa semakin panjang serat kayu maka pulp yang dihasilkan memiliki kekuatan yang tinggi. Hal ini disebabkan serat panjang memberikan bidang persentuhan yang lebih luas dan anyaman lebih baik antara satu serat dengan lainnya, yang memungkinkan lebih banyak terjadi ikatan hidrogen antar serat-serat tersebut. Lebih lanjut, pulp serat panjang lebih sulit lolos saringan, sehingga lebih mudah dicuci. Panjang serat mempengaruhi sifat-sifat tertentu pulp dan kertas, termasuk ketahanan sobek, kekuatan tarik dan daya lipat.

Diameter serat bambu Haur lebih kecil dari bambu Temen dan bambu Tali. Demikian pula diameter lumen bambu Haur lebih kecil dari bambu Temen dan bambu Tali. Tebal dinding serat bambu Haur sebesar 4,60 $\mu \mathrm{m}$ lebih tipis daripada bambu Tali yaitu 5,96 $\mu \mathrm{m}$ dan bambu Temen yaitu $6,08 \mu \mathrm{m}$. Serat yang berdinding tipis mengakibatkan serat tersebut mudah pipih sehingga menghasilkan lembaran pulp dan kertas yang lebih padat dan ketahanan retak lebih baik dibandingkan dengan serat berdinding tebal. Sebaliknya, serat berdinding tebal menghasilkan lembaran yang mempunyai kekuatan ketahanan sobek yang tinggi, tetapi ketahanan retaknya rendah. Untuk memperoleh ketahanan retak dan sobek yang tinggi, serat yang berdinding tebal perlu dicampur dengan serat yang panjang dan berdinding tipis (Syafii dan Siregar, 2006; Fitriasari dan Hermiati, 2008)

\section{Turunan Dimensi Serat}

Selain panjang serat, persyaratan serat untuk bahan baku pulp dan kertas juga ditentukan oleh nilai turunan dimensi serat. Nilai turunan dimensi serat (bilangan Runkel, perbandingan Muhlsteph, fleksibilitas, koefisien kekakuan) dan nilai kelas serat untuk serat bambu dapat dilihat pada Tabel 1 dan Tabel 2. Tabel 1 menunjukkan bahwa bilangan Runkel untuk bambu Tali adalah 0,87 lebih besar dari bambu Haur dan bambu Tali. Bilangan Runkel adalah perbandingan 2 kali tebal dinding sel dengan diameter lumen. Berarti bilangan Runkel berbanding lurus dengan tebal dinding sel dan berbanding terbalik dengan diameter lumen. Menurut Anonim (1976) bilangan Runkel yang kecil atau sama 0,25 termasuk kelas I, ketiga jenis bambu termasuk ke dalam kelas III. Bahan baku untuk pembuatan pulp serat yang baik yaitu memiliki bilangan Runkel kecil atau sama dengan 0,25 karena memiliki dinding sel yang tipis dan diameter lumen lebar sehingga serat dalam lembaran pulp dapat pipih seluruhnya dan ikatan antar serat baik (Syafii dan Siregar, 2006; Fitriasari dan Hermiati, 2008).

Nilai daya tenun yang dihasilkan dari bambu berkisar antara 122-159 (Tabel 1). Nilai daya tenun merupakan perbandingan panjang serat dengan diameter serat. Semakin besar perbandingan tersebut maka semakin tinggi kekuatan sobek dan semakin baik daya tenun seratnya. Dengan kekuatan sobek yang tinggi itu juga berarti panjang serat juga semakin panjang karena dalam menjalin antara serat semakin panjang dan gaya sobek akan terbagi dalam luasan yang lebih besar (Syafii dan Siregar, 2006). Menurut Anonim (1976), nilai daya tenun ketiga jenis bambu tersebut termasuk ke dalam kelas I karena berkisar dari 122 sampai dengan 159. Perbandingan Muhlsteph serat dari bambu 
tersebut berkisar antara 68-71 (Tabel 2). Menurut Anonim (1976), maka dari ketiga bambu tersebut termasuk ke dalam kelas perbandingan Muhlsteph Kelas III, dengan perbandingan Muhlsteph 60-80. Besarnya perbandingan Muhlstep berpengaruh terhadap kerapatan lembaran pulp yang pada akhirnya berpengaruh pula pada kekuatan pulp yang dihasilkan. Semakin kecil perbandingan Muhlsteph maka kerapatan lembaran pulp yang dihasilkan akan semakin tinggi dengan sifat kekuatan tinggi pula. Sebaliknya, perbandingan Muhlsteph yang tinggi menghasilkan lembaran pulp dengan kerapatan yang rendah dan kekuatan rendah pula.

Koefisien kekakuan ketiga jenis bambu berkisar antara 0,22-0,23 (Tabel 1). Nilai koefisien kekakuan adalah perbandingan tebal dinding sel dengan diameter serat. Perbandingan ini menunjukkan korelasi negatif terhadap kekuatan panjang putus (kekuatan tarik), artinya semakin tinggi koefisien kekakuan maka semakin rendah kekuatan tarik dari kertas tersebut. Sebaliknya semakin rendah koefisien kekakuan maka semakin tinggi kekuatan tarik kertas bersangakutan. Maka untuk pembuatan pulp sebaiknya mempunyai nilai koefisien kekakuan yang rendah (Syafii dan Siregar, 2006). Kekakuan ketiga jenis bambu masuk ke dalam kelas IV. Perbandingan fleksibilitas dari ketiga jenis bambu adalah 0,54 sampai 0,56 (Tabel 1) sehingga masuk ke dalam kelas III. Perbandingan fleksibilitas adalah perbandingan diameter lumen dengan diameter serat, dimana perbandingan tersebut mempunyai hubungan parabolis dengan kekuatan tarik, artinya serat dengan perbandingan fleksibilitas tinggi berarti serat tersebut mempunyai tebal dinding yang tipis dan mudah berubah bentuk. Kemampuan berubah bentuk ini menyebabkan persinggungan antara permukaan serat lebih leluasa sehingga terjadi ikatan serat yang lebih baik dan akan menghasilkan lembaran pulp dengan kekuatan baik (Syafii dan Siregar, 2006; Fitriasari dan Hermiati, 2008).

Jumlah nilai panjang serat dengan nilai turunan dimensi serat menghasilkan nilai kualitas serat untuk ketiga jenis bambu tersebut berdasarkan Tabel 2, menurut klasifikasi dari Anonim (1976) termasuk ke dalam kelas II. Dari data tersebut maka ketiga jenis bambu tersebut dapat diinformasikan mempunyai potensi untuk menghasilkan pulp yang baik.

Adapun dari Gambar 1 dan 2 dan dari hasil evaluasi terhadap dimensi serat diketahui bahwa ketiga jenis bambu tersebut merupakan serat panjang yang berpotensi untuk menghasilkan pulp yang baik. Hasil analisis komponen kimia serat memperlihatkan bahwa serat yang digunakan mengandung lignin sekitar $21 \%-23 \%$, selulosa alfa $44 \%-53 \%$ dan hemiselulosa $21 \%-23 \%$. Kadar lignin dan ekstraktif dari bambu Tali relatif lebih rendah dari kedua bambu lainnya. Sedangkan untuk kadar selulosa, bambu Temen memiliki kadar tertinggi, sedangkan bambu Haur yang terendah.

\section{Pulp Bambu}

Proses pemasakan dilakukan dengan proses kraft dengan rasio $1: 5$, pada suhu $165^{\circ} \mathrm{C}$ selama 2 jam, dan dengan memvariasikan konsentrasi alkali aktif dan sulfiditas, dengan tujuan untuk mengetahui pengaruh variasi proses tersebut terhadap bilangan Kappa dan yield dari pulp bambu tersebut. Adapun hasil analisis terhadap pulp bambu disajikan pada Gambar 3 dan Gambar 4.

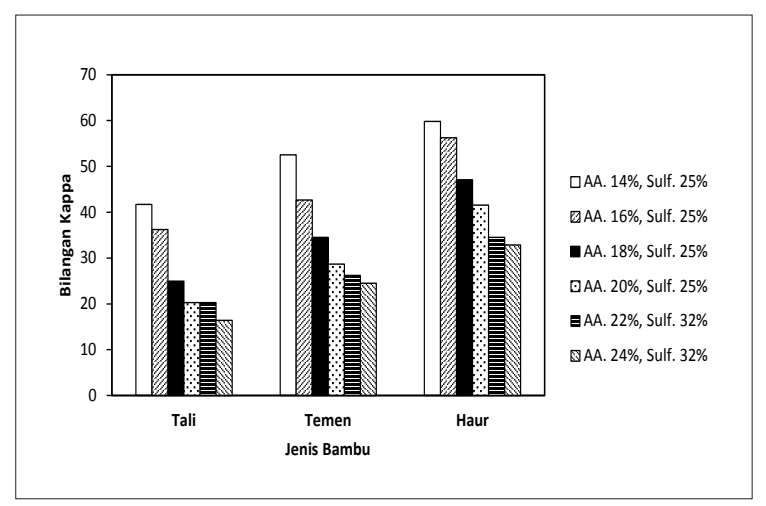

Gambar 3. Pengaruh Alkali Aktif dan Sulfiditas terhadap Bilangan Kappa

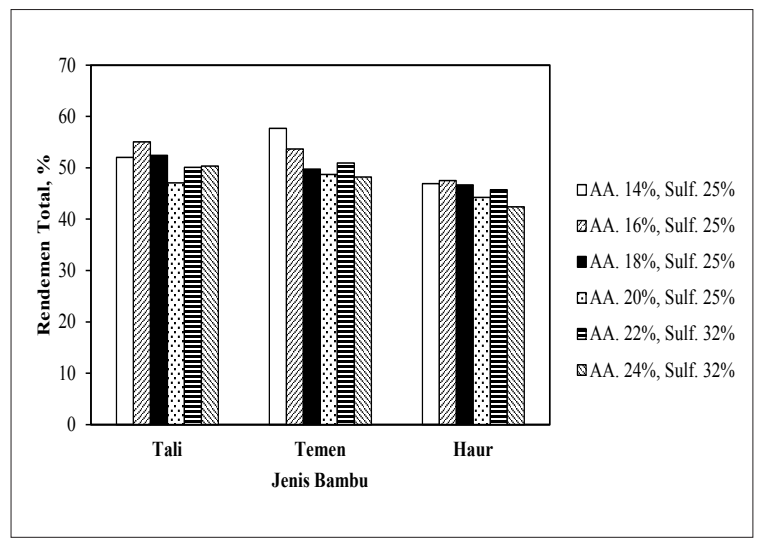

Gambar 4. Pengaruh Alkali Aktif dan Sulfiditas terhadap Rendemen 
Gambar 3 menunjukkan bahwa variasi kondisi proses pemasakan bambu Tali menghasilkan bilangan Kappa yang lebih rendah dibandingkan dengan bambu Temen dan Haur. Hal tersebut kemungkinan besar disebabkan karena kadar lignin dan ekstraktif dari bambu Tali adalah yang paling rendah. Adapun dari Gambar 4 diketahui bahwa rendemen (total yield) dari bambu Temen adalah relatif lebih tinggi dibanding dengan bambu Tali dan Haur. Hal tersebut kemungkinan besar disebabkan karena kadar selulosa alfa dari bambu Temen adalah yang paling tinggi daripada bambu Tali dan Haur. Pada pembuatan komposit, kandungan lignin dalam serat alam yang berfungsi sebagai penguat masih diperlukan, sehubungan dengan sifatnya sebagai perekat, sehingga serat tidak mudah putus/regas atau kekuatan tariknya sangat rendah, begitu halnya untuk pulp bambu. Oleh karena itu, percobaan dilanjutkan untuk memperoleh pulp dengan kadar lignin sekitar 5\% (bilangan Kappa sekitar 30), dengan menggunakan konsentrasi alkali aktif dan sulfiditas yang berbeda-beda, berdasarkan hasil pemasakan tersebut di atas. Adapun hasil ujinya disajikan pada Gambar 5 sampai dengan 7.

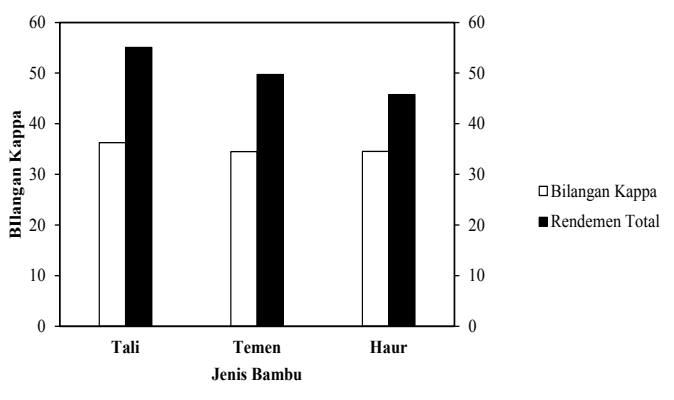

Gambar 5. Hasil Pemasakan untuk Mendapatkan Bilangan Kappa sekitar 30

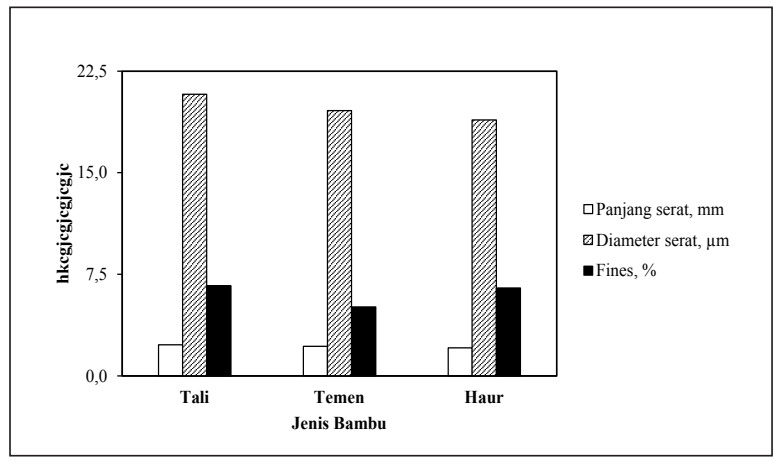

Gambar 6. Morfologi Pulp pada Bilangan Kappa sekitar 30

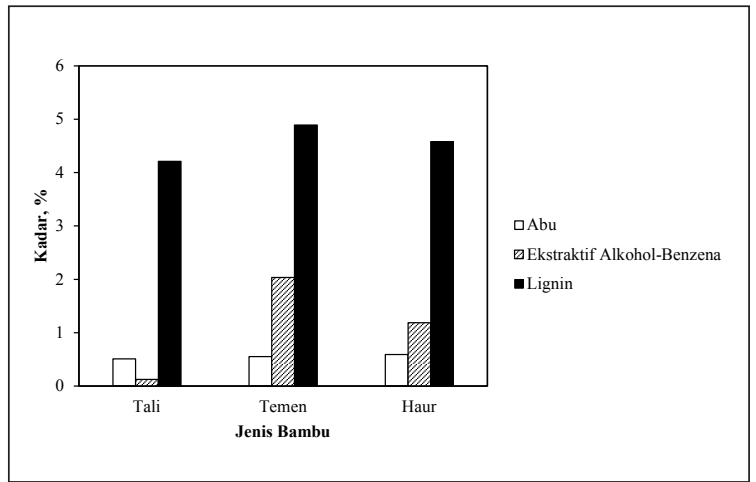

Gambar 7.a. Komponen Kimia Pulp pada Bilangan Kappa sekitar 30

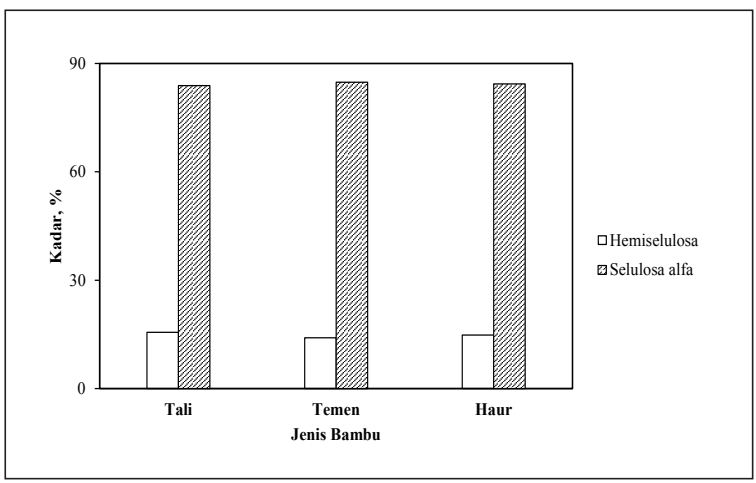

Gambar 7.b. Komponen Kimia Pulp pada Bilangan Kappa sekitar 30

Hasil penelitian menunjukkan bahwa untuk menghasilkan pulp dengan kandungan lignin sekitar 5\% atau bilangan Kappa sekitar 30, maka diperlukan alkali aktif dan sulfiditas dengan konsentrasi yang berbeda-beda. Pemasakan bambu Tali, Temen dan Haur memerlukan alkali aktif dan sulfiditas berturut-turut yaitu, $16 \%$ dan $25 \%, 18 \%$ dan $25 \%$ serta $22 \%$ dan $32 \%$. Dengan demikian diketahui bahwa bambu Tali memerlukan konsentrasi zat kimia yang paling rendah, sedangkan bambu Temen dan terutama bambu Haur memerlukan alkali aktif dan sulfiditas yang relatif lebih tinggi. Hal ini kemungkinan besar disebabkan oleh kadar lignin dan ekstraktif dari bambu Tali adalah yang paling rendah. Penggunaan bahan kimia yang lebih tinggi pada pemasakan bambu Haur disebabkan karena beberapa hal, antara lain kandungan abu, ekstraktif dan lignin.

Dari Gambar 5 diketahui bahwa pada kondisi pemasakan seperti di atas akan dihasilkan pulp dengan lignin dan rendemen berkisar antara $30,43 \%-32,71 \%$ dan $44,13 \%-53,82 \%$. Dari Gambar tersebut diketahui pula bahwa kualitas 
pulp bambu Tali relatif lebih baik dari kedua bambu lainnya. Dari Gambar 6 dan 7 diketahui bahwa, pada kondisi tersebut dihasilkan pulp dengan panjang serat antara $2 \mathrm{~mm}-2,3 \mathrm{~mm}$, diameter $18,9 \mu \mathrm{m}-20,8 \mu \mathrm{m}$ dan fines antara $5,1 \%-6,65 \%$, sedangkan kadar lignin sekitar $4,21 \%-4,89 \%$; selulosa alfa $83,86 \%-84,82 \%$; dan hemiselulosa antara $14,07 \%-15,59 \%$.

Oleh karena proses pemasakan bambu Tali memerlukan konsentrasi bahan kimia yang paling rendah, maka bambu tersebut dipilih untuk menjadi bahan penguat komposit dengan mencampurkannya dengan suatu resin.

\section{Pembuatan Komposit}

\section{Karakteristik Pulp dan Serat Bambu Tali}

Untuk pembuatan komposit digunakan bambu yang terpilih, yaitu bambu Tali. Hasil analisis komponen kimia pulp dan serat bambu setelah proses pemasakan tersebut disajikan pada Tabel 3, sedangkan hasil uji struktur mikro pulp dan serat bambu dengan Scanning Electron Microscope (SEM) disajikan pada Gambar 8.

Tabel 3. Komponen Kimia Pulp dan Serat Bambu

\begin{tabular}{clcc}
\hline \multirow{2}{*}{ No. } & \multicolumn{2}{|}{ Parameter } & \multicolumn{2}{c}{ Bambu } \\
\cline { 3 - 4 } & & Pulp & Serat \\
\hline 1. & Kadar abu, \% & 0,54 & 4,79 \\
2. & Ekstraktif alkohol & 0,15 & 2,30 \\
& bensena, \% & & \\
3. & Lignin, \% & 4,21 & 14,16 \\
4. & Hemiselulosa, \% & 11,38 & 15,90 \\
5. & Selulosa alfa, \% & 83,86 & 66,05 \\
6. & Kadar air & 5,55 & 4,46 \\
\hline
\end{tabular}

Tabel 3 memperlihatkan bahwa kadar lignin, abu dan ekstraktif pulp bambu adalah lebih kecil dibandingkan serat bambu, sedangkan kadar selulosanya lebih tinggi. Seperti telah diuraikan di atas, bahwa hal tersebut disebabkan karena proses pemasakan serat bambu hanya menggunakan soda kostik dengan konsentrasi yang lebih rendah dibanding pemasakan pulp, sehingga lignin, abu dan ekstraktif yang terkandung di dalamnya tidak semuanya dapat didegradasi/dilarutkan. Adapun kadar air pulp dan serat tersebut masih di bawah $7 \%$, sehingga diharapkan tidak berpengaruh pada pembuatan komposit. Gambar 8 memperlihatkan bahwa spesimen serat bambu tampak lebih rapat atau lebih kompak dibanding pulp.

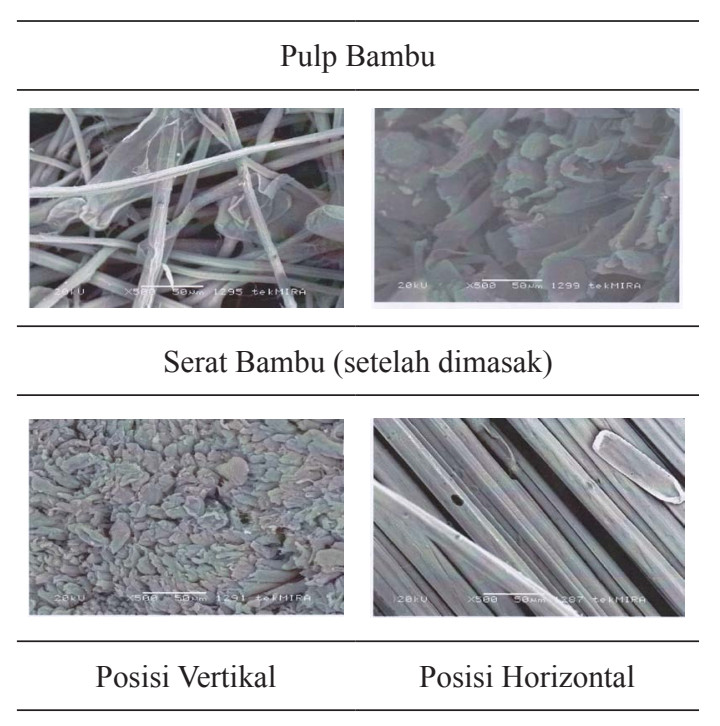

Gambar 8. Struktur Mikro Bambu, Pulp dan Serat Bambu Tali (SEM, 500 X)

\section{Komposit Bambu}

Dari studi literatur dan percobaan awal diketahui bahwa untuk mendapatkan kondisi pembuatan komposit yang optimal, maka perbandingan yang dianggap cukup baik untuk pulp atau serat bambu dan matriks epoksi, yaitu sekitar $1: 1,5$. Hasil uji terhadap komposit yang dihasilkan disajikan pada Tabel 4.

Tabel 4. Karakteristik Komposit Epoksi/Pulp dan Serat Bambu

\begin{tabular}{llcc}
\hline \multirow{2}{*}{ No. } & \multicolumn{2}{c}{ Parameter } & \multicolumn{2}{c}{ Bambu } \\
\cline { 3 - 4 } & & Pulp & Serat \\
\hline 1. & Ketebalan, $\mathrm{mm}$ & 9,50 & 22,00 \\
2. & Kadar air, \% & 28,58 & 11,17 \\
3. & Volume, $\mathrm{cm}^{3}$ & 7,01 & 16,18 \\
4. & Volume $/ \mathrm{berat} \mathrm{cm}^{3} / \mathrm{g}$ & 0,785 & 1,458 \\
5. & Berat jenis, $\mathrm{g} / \mathrm{cm}^{3}$ & 1,273 & 0,686 \\
\hline
\end{tabular}

Tabel 4 menunjukkan bahwa volume komposit serat bambu adalah lebih besar dibandingkan komposit pulp bambu. Hal ini sesuai dengan ketebalan komposit yang dihasilkan, yaitu lebih tebal, namun berat jenisnya lebih kecil/ringan. Diketahui pula bahwa tebal dan volume komposit epoksi/serat bambu pada diameter yang sama adalah sekitar dua kali lebih besar dibanding epoksi/pulp bambu. Hal ini kemungkinan besar 
terjadi karena bentuk fisik pulp yang lebih kompak dibandingkan serat yang lebih bulky, sehingga kemungkinan terjadinya rongga udara pada komposit epoksi/serat menjadi lebih besar.

Selain hal di atas, kemungkinan besar hal tersebut disebabkan karena struktur mikro pulp dan serat bambu yang berbeda (Gambar 8). Dari hasil uji dengan SEM tersebut diketahui bahwa, material penyusun spesimen pulp pada posisi vertikal terlihat adanya rongga udara diantara serat dalam pulp tersebut, sedangkan spesimen serat bambu pada posisi tersebut tampak lebih rapat atau kompak dibanding pulp.

\section{Koefisien Absorpsi Suara}

Pendengaranmanusiastandartanggapterhadap bunyi antara jangkauan frekuensi audio sekitar 20 sampai $20.000 \mathrm{~Hz}$. Pada Umumnya bunyi terdiri dari banyak frekuensi, yaitu komponen frekuensi rendah, tengah, medium. Frekuensi standar yang dapat dipilih secara bebas sebagai wakil yang penting dalam akustik lingkungan adalah 125, $250,500,1000,2000$, dan $4000 \mathrm{~Hz}$ atau 128, 256, 512, 1024, 2048, dan $4096 \mathrm{~Hz}$. Adapun peredam suara adalah suatu bahan yang dapat menyerap energi suara dari suatu sumber suara (Khuriati dkk., 2006; Beranek dkk., 1992; Setyanto dkk., 2011; Merve dkk., 2010).

Untuk mengetahui kemampuan material dalam menyerap suara dilakukan pengukuran dengan menggunakan Tabung Impedansi, pada frekuensi $1000 \mathrm{~Hz}$ sampai dengan $6300 \mathrm{~Hz}$ sesuai kapasitas alat uji. Dengan alat tersebut dapat dihitung koefisien absorbsi suara normal, yaitu dengan cara mengukur tekanan suara (ó) yang datang pada permukaan bahan dan dipantulkan. Adapun hasil pengujian dari contoh uji ditampilkan dalam bentuk grafik atau kurva. Grafik - grafik ini menyatakan hubungan antara parameter akustik dari material uji, yaitu koefisien absorbsi suara, dengan parameter fisik dari material uji, yaitu ukuran dan konfigurasi yang digunakan, disajikan pada Gambar 9.

Dari Gambar 9 diketahui bahwa koefisien absorpsi komposit pulp bambu cenderung naik seiring naiknya frekuensi tinggi, yaitu sampai 3150 $\mathrm{Hz}-5000 \mathrm{~Hz}$, kemudian menurun; sedangkan untuk komposit serat bambu cenderung naik seiring naiknya frekuensi tinggi, yaitu sampai 2500 $\mathrm{Hz}$, kemudian menurun. Diketahui pula bahwa komposit pulp bambu memberikan koefisien absorpsi terbesar pada rentang frekuensi antara
$3150 \mathrm{~Hz}-4000 \mathrm{~Hz}$, yaitu 0,29. Adapun komposit serat bambu pada rentang frekuensi yang sama koefisien absorpsinya adalah $0,83-0,80$.

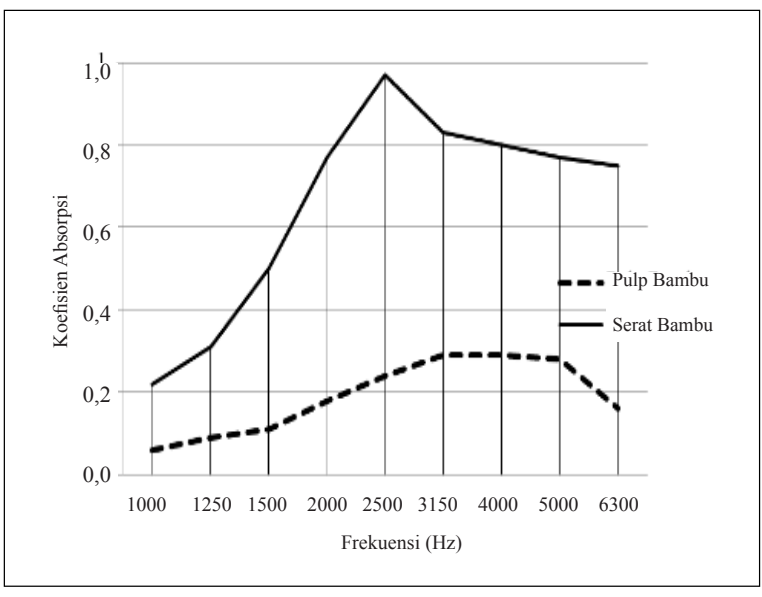

Gambar 9. Koefisien Absorpsi Suara Komposit Epoksi/Pulp dan Serat Bambu

Dari hasil uji koefisien absorpsi suara tersebut diperoleh rata-rata koefisien absorbsi pada frekuensi standar $(1000 \mathrm{~Hz}-4000 \mathrm{~Hz})$ dan frekuensi tinggi $(5000 \mathrm{~Hz}-6300 \mathrm{~Hz})$, seperti terlihat pada Tabel 5. Dari Tabel tersebut diketahui bahwa komposit berpenguat serat bambu pada frekuensi standar memberikan koefisien absorpsi suara relatif tinggi dengan kondisi maksimum $\alpha=0,97$ pada frekuensi 2500 $\mathrm{Hz}$ (rentang frekuensi berdasarkan kemampuan dari sound system atau speaker yang umum digunakan adalah $0-2800 \mathrm{~Hz}$ ). Demikian juga pada frekuensi tinggi komposit pulp dan serat bambu memberikan kondisi maksimum dengan $\alpha$ $=0,28$ dan 0,77 pada frekuensi $5000 \mathrm{~Hz}$. Dengan demikian komposit tersebut telah memenuhi standar minimal koefisien serap bunyi, yaitu $\alpha$ $=0,25$ pada frekuensi acuan $(5000 \mathrm{~Hz})$ berdasar ISO 11654:1997 (Setyanto dkk., 2011).

Serat bambu merupakan serat selulosa dan apabila ditinjau dari segi komposisi kimianya, kandungan selulosa alfa bambu untuk pulp $(83,86 \%)$ adalah lebih besar dari seratnya $(66,05 \%)$ (Tabel 4). Hal ini memungkinkan rantai molekul polimer selulosa pada pulp bambu lebih panjang yang dihubungkan oleh ikatanikatan hidrogen. Rantai selulosa ini merupakan struktur kristalin yang ditunjang dengan ikatanikatan kovalen antar unsur-unsurnya. Adanya gugus-gugus hidrogen pada polimer resin Epoksi akan berikatan dengan gugus-gugus aktif pada selulosa yaitu gugus $\mathrm{OH}$ dan $\mathrm{CH}_{2} \mathrm{OH}$ membentuk 
ikatan hidrogen. Semakin panjang rantai molekul selulosa maka semakin banyak ikatan kimia yang terjadi dengan polimer resin, sehingga komposit akan lebih padat dan memungkinkan pada area macroporous maupun microporous terisi penuh oleh ikatan-ikatan kimia. Secara visual komposit pulp bambu menunjukkan sifat yang lebih kompak dan padat, karena derajat kristalinitas bahan pengisinya lebih tinggi dan dimungkinkan beban matriks yang ditransfer ke bahan pengisi melalui antar muka lebih besar, sehingga ikatan kimia dan ikatan mekanik antara serat dengan matriks polimer yang terjadi lebih kuat. Pada komposit serat bambu, dimungkinkan ikatan antar muka dengan matriks resin kurang sempurna dibandingkan komposit pulp bambu, karena kandungan $\alpha$ selulosanya relatif lebih rendah, sehingga resin sebagian menumpuk dan berpolimerisasi pada permukaan serat, menyebabkan komposit yang dihasilkan jauh lebih tebal. Oleh karena itu, dari hasil pengukuran diperoleh volume komposit serat bambu yang lebih besar (Tabel 4), walaupun komponen berat pulp atau serat bambu dan resin yang digunakan sama.

Volume tertinggi diperoleh pada komposit serat bambu, dengan demikian kemungkinan porositas komposit serat bambu menjadi lebih besar dibandingkan komposit pulp bambu. Porositas tersebut merupakan udara yang terperangkap dalam komposit (void). Void dalam material komposit dapat disebabkan tekanan yang tidak rata, resin yang menguap, udara yang terperangkap dalam resin pada saat pengadukan, atau pencampuran yang tidak homogen.

Serat bambu sebagai penguat komposit tersebut masih mengandung senyawa lain seperti lignin dan hemiselulosa yang merupakan pembentuk non kristalin, sehingga serat tidak terisi polimer resin atau tidak terdapat ikatan kimia dengan resin atau ikatan mekanik, maka udara dalam serat akan lebih banyak terkandung dalam komposit yang memungkinkan volume void dalam komposit serat bambu relatif besar. Besarnya volume void menunjukkan bahwa sifat porositasnya lebih besar dibandingkan komposit pulp bambu, sehingga koefisen absorpsi komposit tersebut lebih tinggi. Selain itu, untuk material yang berpori kemampuan absorbsi suara bergantung pada volume dan ketebalan, semakin besar volumenya dan semakin tebal material akan semakin tinggi koefisien absorbsi suara yang terjadi, sehingga memungkinkan komposit dengan penguat serat bambu, pada frekuensi standar maupun tinggi memberikan koefisien absorpsi suara relatif tinggi atau mempunyai daya peredam suara lebih baik daripada komposit pulp bambu.

Secara umum absorber suara dapat diklasifikasikan ke dalam 3 golongan, yaitu Porous Absorber, Membran Absorber dan Cavity Absorber, dan komposit serat bambu ini termasuk Porous Absorber atau bahan yang memiliki pori-pori dan volumenya adalah jauh lebih besar dibanding komposit pulp bambu. Melalui poripori ini gelombang suara masuk dan menggetarkan molekul udara dalam pori-pori tersebut. Molekul udara yang bergetar akan bergesekan dengan permukaan bahan dan menghasilkan panas. Absorber ini lebih efektif pada gelombang suara dengan frekuensi tinggi dan panjang gelombang pendek (Shoshani, 2011).

Dari studi pustaka diketahui bahwa koefisien absorbsi suara glasswool pada frekuensi suara

Tabel 5. Koefisien Absorpsi Suara Komposit Pulp dan Serat Bambu

\begin{tabular}{lccc}
\hline \multirow{2}{*}{ Komposit } & \multirow{2}{*}{ Frekuensi $(\mathrm{Hz})$} & \multicolumn{2}{c}{ Koefisien Absopsi Suara $(\alpha)$} \\
\cline { 3 - 4 } & & Rata-rata & Optimum \\
\hline \multirow{2}{*}{ Pulp bambu } & Standar $(1000-4000)$ & 0,18 & $0,29(\mathrm{a})$ \\
& Tinggi $(5000-6300)$ & 0,22 & $0,28(\mathrm{~b})$ \\
& Standar $(1000-4000)$ & 0,62 & $0,97(\mathrm{c})$ \\
Serat bambu & Tinggi $(5000-6300)$ & 0,76 & $0,77(\mathrm{~b})$ \\
\hline Keterangan : & & & \\
a. Pada $3150-4000 \mathrm{~Hz}$ & & & \\
b. Pada 5000 Hz & & & \\
c. Pada 2500 Hz & & &
\end{tabular}


antara $250 \mathrm{~Hz}$ sampai $2000 \mathrm{~Hz}$ rata-rata adalah antara 0,4 sampai dengan 0,8 , sedangkan koefisien absorbsi suara pada bahan kayu, ubin dan dinding pada frekuensi suara antara $125 \mathrm{~Hz}$ sampai dengan $4000 \mathrm{~Hz}$, rata-rata berturut-turut antara $0,06-0,15 ; 0,4-0,8$; dan $0,3-0,7)$ (Erlina Rusmawati; Mediastika, 2005; Shoshani, 2011). Adapun gambaran mengenai koefisien absorbsi suara komposit bambu, kayu dan dinding dapat dilihat pada Gambar 10.

Dengan membandingkan koefisien absorpsi suara komposit bambu hasil percobaan di atas dengan koefisien absorpsi glasswool, kayu dan dinding (Gambar 10), diketahui bahwa komposit serat bambu dengan ketebalan 22 mm menunjukkan $\alpha$ yang lebih tinggi daripada glasswool, yaitu 0,97 atau mampu menyerap 97\% suara pada frekuensi $2500 \mathrm{~Hz}$; dan mempunyai nilai yang relatif mendekati koefisien absorpsi glasswool pada frekuensi sekitar $2000 \mathrm{~Hz}$. Selain itu kemampuan untuk mengabsorpsi suara, terutama komposit serat bambu adalah lebih besar daripada kayu dan dinding.

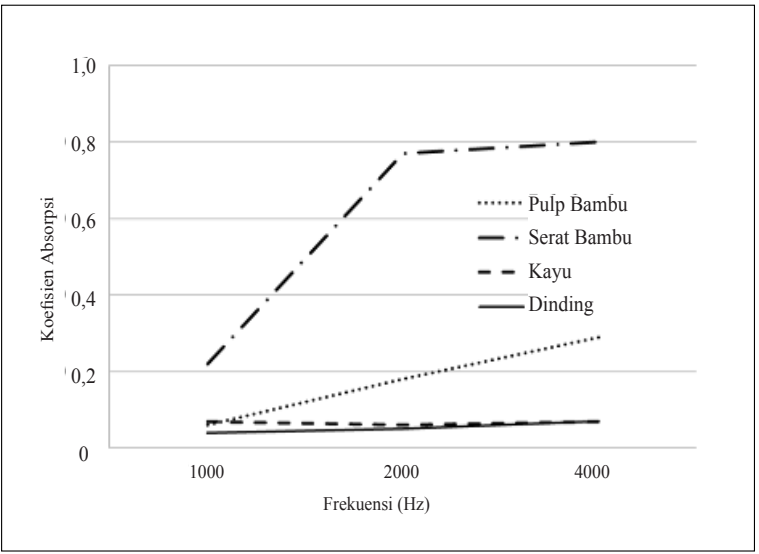

Gambar 10. Koefisien Absorbsi Suara Komposit Epoksi/Pulp dan Serat Bambu

Dari uraian di atas diharapkan serat bambu dapat dimanfaatkan sebagai bahan peredam suara, karena mampu meredam suara sampai 97\% dan produknya relatif ringan. Selain itu dapat mengurangi pemakaian serat sintetis dan resin, sehingga lebih ramah lingkungan

\section{KESIMPULAN}

Penelitian ini telah berhasil membuat komposit yang memenuhi standar minimal koefisien serap bunyi $(\alpha=0,25)$ pada frekuensi acuan berdasarkan ISO 11654:1997, dengan menggunakan serat dan pulp bambu serta resin epoksi. Dengan demikian produk tersebut dapat digunakan sebagai peredam suara, terutama komposit epoksi/serat bambu, karena mampu meredam suara sampai $97 \%$ (pada frekuensi 2500 $\mathrm{Hz}$ ) dan lebih ringan (berat jenis $0,686 \mathrm{~g} / \mathrm{cm}^{3}$ ). Selain itu, komposit yang dihasilkan lebih ramah lingkungan, karena dapat mengurangi pemakaian serat sintetis dan resin.

\section{DAFTAR PUSTAKA}

Airna, S., 2011. Hubungan Kebisingan dan Kelelahan Tenaga Kerja Shift Pagi di Bagian Weaving II PT. Dan Liris Sukoharjo. UNS Digital Library, 2005-2011 UPT.Puskom - UPT. Perpustakaan (diunduh Oktober 2013)

Anonim, 1976, Vademecum Kehutanan Indonesia, Departemen Pertanian, Direktorat Jenderal Kehutanan, Jakarta.

Beranek, Leo L., Ver, Istvan L., 1992. Noise and Vibration Control Engineering: Principle and Application, John Wiley and Sons Inc., New York

Chen, W., Y. Yu, P. Li, C. Wang, 2007, Effect of New Epoxy Matrix for T800 Carbon Fiber/Epoxy Filament Wound Composites, Composite Science and Technology, Vol. 67, $2261-2270$

Eriningsih, R., Mutia, T., Judawisastra, H., 2011, Komposit Sunvisor Tahan Api dari Bahan Baku Serat Nanas, Jurnal Riset Industri, Vol. V., No. 2,191-203

Fitriasari, W., Hermiati, E., 2008, Analisis Morfologi Serat dan Sifat Fisis-Kimia Enam Jenis Bambu Sebagai Bahan Baku Pulp dan Kertas, Jurnal Ilmu dan Teknologi Hasil Hutan, 1(2), 67-72

Franck, R. R., 2005, Bast and Other Plant Fibers, The Textile Institute, Woodhead Publishing Ltd., Cambridge England

Judawisastra, H., Abdulah, A. H. D., Ariewahjoedi, B., 2006, Pengaruh Perlakuan Silana Terhadap Kekuatan Geser Komposit Serat Alam-Poliester, Prosiding Simposium Nasional Polimer VI, 71-75

ISO 10534-2: Acoustics - Determination of sound absorption coefficient and impedance in impedance tubes - Part 2: Transfer-Function Method. 1998. International Standardization Organization 
Khuriati, A., Komarudin, E., Nur, M., 2006, Disain Peredam Suara Berbahan Dasar Sabut Kelapa dan Pengukuran Koefisien Penyerapan Bunyinya, Berkala Fisika, No.1, Januari, 15 - 25

Mazumdar, S. K., 2002, Composites Manufacturing: Material, Product and Processing Engineering, CRC Press, Taylor \& Francis Group

Mediastika, E. C., 2005, Akustika Bangunan: Prinsip-prinsip dan Penerapannya di Indonesia, Erlangga, Jakarta

Merve, K. O., Bunu, U. N., Cevza, C., 2010. A Study on the Influence of Fabric Structure on Sound Absorption Behavior of Spacer Knitted Structures. International Conference - TEXSCI, September 6-8, Liberec, Czech Republic, Istanbul Technical University, Department of Textile Engineering, Istanbul, Turkey

Miasa, I. M., Sriwijaya, R., 2004, Penelitian Sifat Akustik dari Bahan Kertas dan Plastik Sebagai Penghalang Kebisingan, Media Teknik, No.1, Tahun XXVI, 68-71

Pasaribu, R. A., Tampubolon, A.P., 2007, Status Teknologi Pemanfaatan Serat Kayu Untuk Bahan Baku Pulp. Workshop Sosialisasi Program dan Kegiatan BPHPS Guna Mendukung Kebutuhan Riset Hutan Tananam Kayu Pulp dan Jejaring Kerja (tidak dipublikasikan)
Pramono, A. E., 2012, "Karakteristik Komposit Karbon Berbasis Limbah Organik Hasil Proses Tekan Panas", Disertasi, Universitas Indonesia

Rusmawati, E., 2010. Penentuan Koefisien Absorbsi Dengan Metode Dua Mikrofon pada Tabung Impedansi. Skripsi. Institut Teknologi Sepuluh Nopember

Sabri, 2005. "Evaluasi Kinerja Akustik Serat Alam Sebagai Material Alternatif Pengendali Kebisingan”, Tesis, Institut Teknologi Bandung

Setyanto, R. H., Priyadithama, I., Maharani, N. 2011, Pengaruh Faktor Jenis Kertas, Kerapatan dan Persentase Perekat Terhadap Kekuatan Bending Komposit Panel Serap Bunyi Berbahan Dasar Limbah Kertas dan Serabut Kelapa, Performa,Vol. 10, No. 2, 89-94

Shoshani, Y. Z., 2011, Effect of Nonwoven Bacing on the Noise Absorption Capacity of Tufted Carpets. Textile Research Journal, 60, 452-456

Syafii, W., Siregar, I.Z., 2006. Sifat Kimia dan Dimensi Serat Kayu Mangium (Acacia mangium Wild) dari Tiga Provenans, Jurnal Ilmu dan Teknologi Kayu Tropis, Vol. 4. No. 1, 29-32

Tampobolon, E., 2010, "Pembuatan dan Karakterisasi Papan Serat yang dibuat dari Serat Tandan Kosong Kelapa SawitUrea Formaldehida", Skripsi. Universitas Sumatera Utara 